\title{
A Study of Class Discrimination in A Rose for Emily From the Perspective of Western Marxist Criticism
}

\author{
HOU Xia \\ College of Foreign Languages, Zhoukou Normal University, Zhoukou, China, 466001
}

\begin{abstract}
A Rose for Emily is a short story written by William Faulkner, an American modernist novelist, in the first half of the 20th century. This paper tries to analyze the class structure and class discrimination in the Southern United States from the perspective of Western Marxist literary criticism in the 19th to 20th centuries of the text, and further expand the thematic significance of the literary text.
\end{abstract}

Keywords: A Rose for Emily, Western Marxist Criticism, class discrimination

William Faulkner (1897-1962) is a Southern American writer. He was born in Oxford, which is also the prototype of Jefferson, the place where the story takes place in his short story A Rose for Emily. Faulkner's grandfather had a prominent position in the last three generations, and his Southern values made him respect tradition, so he continued the name of his grandfather Falkner (Faulkner added "u” to his grandfather's name). Faulkner, influenced by his mother, read extensively the Western classics of Shakespeare, Fielding, Voltaire, Dickens, Hugo, Balzac, Conrad, etc. Young Faulkner liked to listen to the stories about the past of his hometown, such as the war stories told by the veterans of the Civil War, and the indomitable and never-defeated spirit of the Southern women told by the elders. In his father's generation, because of the poor operation of the railway company, the family was in a downturn. Growing up in this environment, Faulkner was in a contradiction between the call of remembering the glorious past and the need to seek his own personal identity. On the one hand, Faulkner is influenced by the dark and distant, powerful Southern tradition, which made people unable to escape. On the other hand, the modernization of the North attracts him to look for his original vision. Therefore, Faulkner's creative perspective has dual characteristics, that is, to look at the world in two different ways.

A Rose for Emily is full of Faulkner's ambivalence of nostalgia and suspicion for his Southern homeland, and shows its rich customs, human feelings and strict class hierarchy concept. According to the Western Marxist Literary Criticism Theory, human economic activities are the basis of realizing the existence of superstructure, which includes politics, social ideology, and so on. Economic power always includes social and political power, which is why many Marxist critics today refer to the socio-economic class rather than the economic class when they talk about class structure. Marxist analysis of events and product knowledge in human society always focuses on the relationship between social and economic strata, which can occur within a society or between different societies. According to this analysis, human activities can be explained according to the distribution and

HOU Xia, MA, Associate Professor, College of Foreign Languages, Zhoukou Normal University, Zhoukou, China. 
changes of economic rights. From the point of view of Marxist thought, the difference of social and economic strata has caused a far greater degree of differentiation than that of religious races. Ethnic or gender differences have caused the differentiation of human beings. On the basis of Marxist theory, this paper probes into the social class structure and class discrimination reflected in this novel, and deepens Faulkner's research on the theme of creation from his dual perspectives to the South.

\section{The Social Class Structure of Southern America in the Time of A Rose for Emily}

A Rose for Emily reflects the elements and distribution of class structure in the 19th and 20th centuries in the South of the United States. Before 1800, however, there was no class concept in the South, because most of the early colonists were poor. Even if there were a few nobles, the number was very small. European immigrants came to the new land and initially lived in low-lying coastal areas. Later, the number of people living in low-lying coastal areas increased, and some people were flexible enough to move to the Midwest and reclaim more land. They began to grow tobacco for export to Europe, and later plant cotton in large quantities as European smokers declined and Indian tobacco became competitors. Later, with the limitation of fertile land, American colonists began to expel indigenous Indians to grasp more lands, buy more slaves from Africa for more free labor, and expand the economic production of plantations. The vast majority of cotton imported from Europe in the 19th century came from the United States, and a group of people made a fortune. When their economic status rose, they began to consider the uniqueness of their class. For one and a half centuries, they had been busy with the creation of genealogy, or making up the ancestors of some celebrities who participated in the amendment of the Constitution and so on. The upper aristocracy spends a lot of money on educating their children. They set up their own family libraries and concerts and they were with unique dress requirements and codes of conduct. Owners of farms spent most of their time traveling around the world. The individual aristocracy owned more than 1,000 acres of land, but every farmer had about 100 to 400 acres of land. Nobles bribed government officials to obtain more land permits and used lands as a bargaining chip. Priests and other clergy constrained people with theocracy from the beginning of colonial establishment, so government officials and priests were in the second top class, while farmers and businessmen were in the third level. They could join the ranks of aristocracy in two ways, to marry the aristocracy (to become a semi-aristocrat), or to accumulate a lot of wealth by their hard-working or intelligence. In 1793, due to the wide application of cotton stick machine, the speed of separating cottonseed from cotton lint increased by at least 50 times than before. Some farmers seized the opportunity to become upstarts. During this period, cotton exports from the United States to Europe accounted for almost all of the cotton exports. Later, as plantation lands were cultivated year after year, they became barren, and import and export tariffs were raised in the north, which directly affected the export of tobacco and cotton. Businessmen took the opportunity to make usurious loans, rent seeds, and farm tools. If the peasants and nobles could not pay less than $45 \%$ or $50 \%$ interest next year, part of their lands would be occupied by businessmen. So the Southern classes were not unchanged and had certain mobility. Some farmers, upstarts, and businessmen who issued usury, were gradually entering the upper class, while some of the traditional aristocracy were likely to decline. But the chances were slim for the poor white people at the bottom of society and American slaves who could not even obtain freedom. The social and economic class structure of the Southern America from the end of the 19th century to the beginning of the 20th century is shown in Figure 1. 


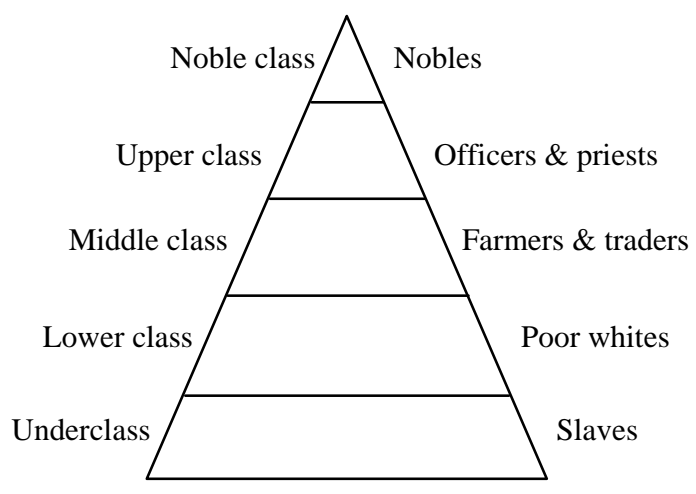

Figure 1. Classes in Old South of America.

\section{Class Discrimination in A Rose for Emily}

A Rose for Emily reflects the conflicts between different classes in the old South of America. Emily confronted to all of the classes with great bravery and dignity. She usually raised her head high or stare back the one who said "no" to her. On the face of gossip or curiosity, she just acted as herself and was not bothered by them, which shows her courage and overwhelming spirit. Emily, who was at the top of the pyramid of classes, was always the winner, which is not only the result of her stubborn proud personality, but is also more because of her high status in the town. The following passage presents confrontations between the noble class represented by Emily and other comparatively inferior classes.

\section{Class Discrimination Between Nobles Represented by Emily and the Upper Class}

The first chapter of the text describes Emily's confrontation with government officials. In the face of the delegation of members of Parliament who stood up to show respect, Emily did not let them sit down. Instead, she looked at them one by one with her little coal-ball eyes, while the delegates stumbled under heavy pressure to report their intentions of collecting tax. Emily interrupted three times in her next conversation with the deputies. They asked Emily whether received a tax notice from the county sheriff. Emily answered, "Yes, I received a paper”. Emily did not admit he was the county sheriff. In Emily's words, we can picture how arrogant she is. She regarded the tax receipt as a waste paper. She thought that the magistrate was appointed by himself. He had no power to control her and ignored authority and law. She mentioned four times that "I have no taxes in Jefferson". Her attitude was extremely arrogant and she despised everything. Finally, she let her slave drive the senators away. The second chapter of the text suggests Emily's high social status. Even Steven, the 80-year-old mayor and judge, had nothing to do with Emily. When a woman complained that Emily's house smelled bad, the mayor said that he could talk to him (Tobe, Emily's slave), implying that he dared not deal directly with Emily, but only let the slave tell his master, which shows the great disparity between their status. When more people complained about smells, the judge scolded, "Dammit, sir. Will you accuse a lady to her face of smelling bad?" The implication itself was an insult to Emily. Although she could be legally ordered to stop the volatilization of odor, culture and values did not allow local residents to treat a noble lady like this.

The women in the town forced the Episcopal priest to call on Emily to dissuade Emily and Homer. The priest was unwilling to reveal what had happened and refused to visit again. The narrator uses ellipsis to arouse readers' imagination. It is not difficult to guess that the priest's situation was the same with that of the 
parliamentary delegation asking for taxes, or even worse. The clergies in the South of the United States were highly respected and respected by everyone. However, on the face of Emily, they are inevitably left out and even humiliated. The psychological gap and the severity of humiliation are all vividly reflected in the words of the clergy, which also fully shows the severity of class discrimination.

\section{Class Discrimination Between Nobles Represented by Emily and the Middle Class}

When Emily went to buy arsenic, she did not say hello. She said directly that she wanted some poison. Her eyes were cold and her facial muscles were tense. The drugstore owner responded warmly, "Yes, Miss Emily. What kind? For rats and such? I'd recom...” Before the last word of the recommendate came to an end, Emily interrupted him and said, "I want the best you have. I don’t care what kind”. The drugstore owner enumerated several varieties courteously, “Do you want...?” Before he finished, Emily interrupted, “Arsenic”. "Is that a good one?” "Is ... arsenic? Yes, ma’am. But what you want...? On hearing that, she looked up at the drugstore owner angrily. Even though Emily was not very tall, her face was like a tight flag. In other words, she wanted arsenic; whatever her purpose is! The drugstore owner quickly explained, "If that's what you want. But the law requires you to tell what you are going to use it for”. But Emily still looked up at him and did not respond. The owner had to go inside to pack the medicine. He asked the black child to take out the package. The drugstore owner wrote the words "For Rats" on it, which means it had nothing to do with me. It shows the legal concept of foreigners, but also reflects Emily's victory and arrogance as an aristocrat.

Emily's relationship with farmers was very complicated. The whole town went to Emily's funeral. When Emily's father died, they were very happy because they finally had the opportunity to pity her, which also reflected people's complacency about the decline of the upper class. But because Emily's father died, she was ill, and then they were worried about her health. At the beginning, they were also very happy when Emily and Homer fell in love. But soon, the women in the town began to whisper, behind the silk curtains, in the cracks of their fingers: "Poor Emily". "She's a bad example". "She disgraces the dignity of the nobility". Men did not want to interfere. Although women dared not blame her directly, they forced the priest to dissuade her. After the priest was humiliated, his wife came to Emily's cousins to persuade her. But when her cousins arrived, we all stood on Emily's side, because the cousins more represented the aristocratic status of the Grierson family. Townspeople always supported the weak to fight against the strong. The attitude of the peasants towards Emily was swinging. Sometimes they sympathized with her decline, sometimes they rejoiced in her misfortunes, sometimes they respected her nobility, while sometimes they hated her high status. It also reflects the contradiction between the complexity of human nature and the internalized respect and instinctive resistance of class discrimination. Obviously men and women have different attitudes towards Emily. For example, men were unwilling to disturb Emily, but they liked to do something for her. Four men sneaked into Emily's house at night, and then sprinkled lime on the corner of the wall and beside the cellar to cover up the odor. At the funeral, men were with respectful love, while women were out of curiosity. When Emily and Homer fell in love, men were unwilling to interfere, but women forced priests to go to her home, which shows that women were nosy and aggressive. But these were not worth mentioning in Emily's eyes. Even when everyone thought Emily had fallen, Emily raised her head and went her own way. The words and pressures of the middle class had no effect on Emily, in that Emily has always been at the top of the society with the differences in ranks and the sense of superiority of the nobility. 


\section{Class Discrimination Between Nobles Represented by Emily and the Lower Class}

Although Homer did not come from the South, according to the classification criteria of social classes in the South, he belonged to the poor white lower class, because he had no land and was paid by working hours daily. His only difference was that he was cheerful, laughed loudly, soon mingled with everyone, and was always at the center of the crowd. Emily was at the top of the society and fell in love with a member of the lower class, which reflects her strong desire to pursue a new life of freedom. Every weekend she rided with Homer. But in a bar Hermer told people that he was not prepared for marriage, because he liked men. This was a fatal blow to Emily. As an aristocrat, her dignity, value, and honor did not allow Homer to leave. It is not difficult for us to understand that whether Homer is alive or dead, as long as Emily lives with him, it proves the fact that their marriage exists, and the maintenance of marriage shows the values and honors of the southern aristocracy. Emily wanted to jump out of the limitations of this class at first, but ultimately embodied and maintained the class boundaries. The concept of hierarchy hindered Emily's individual consciousness of happiness and independence from the beginning to the end. Emily did not have the ability to control Homer's thought, but she could deprive of his life in order to defeat him forever. Nobody could provoke her. Her selfishness and cruelty were also the conponents of her nobility.

\section{Class Discrimination Between Nobles Represented by Emily and the Underclass}

The slave Tobe accompanied Emily all his life, from a young age, carrying a basket in and out, until his hair turned white and his waist bent, still carrying a basket in and out. He faithfully fulfilled any orders given by his master, such as greeting the delegation of parliamentarians, and expelling guests. When Emily was dead, townspeople were led into her house, and then the slave never appeared again. Why did the black man choose to disappear in this period, which was after the Civil War? The slaves were liberated and freed at that time. But Tobe did not leave her, even his voice was unused for a long time, and he did not tell anyone about the murder in his master's house, which reveals that white people's ideological slavery was deeply rooted and completely internalized into his mind. He was willing to do everything for Emily. In addition, the name of the slave Tobe implies existence. As in shakespeare's drama Hamlet, the protagnist said, "To be or not to be , this is a question." It means: "To live or not to live, this is a question." From his name, readers can speculate that slaves were just the appengage of their owners. However, his existence was only depended on the aristocratic rule of the plantation economy. If the aristocrat disappears, the slave has no value of existence.

\section{Conclusion}

Emily defeated all classes, from the underclass to the upper class. Her tone, her voice, her words, her facial expressions, her deeds and her thoughts all proved that she was the top of society. However, she completely obeyed her father's choice. Father whipped away all the young people who came to propose marriage, probably out of love for their daughters. Because of their different class status, the young men who proposed marriage may have the mentality of changing their status through marriage, instead of genuine affection to Emily. Her father refused to allow inferior classes to marry his daughter. Emily had not married since she was 30 . Her father's excessive love and the maintenance of class status also buried Emily's youth and happiness. Emily finally inherited the spirit and dignity of her father. As a representative of the declining aristocracy, she won a great victory. At first glance, it is inconceivable. However, from the view of Marxist economic view on superstructure, 
its reason lies in the deep-rooted ideology of class hierarchy and class discrimination in the old South of the United States. Faulkner's superb sculpting brushwork painted a picture of the classes of his hometown. Does the implied author hold a positive or critical attitude towards it? We can get conclusion from Emily's funeral. Even the higher class cannot escape the fate of extinction, all of which are like dust in Emily's house, circling back to the earth. The implied author will never give up, nor will he cast away the tradition, value, responsibility, honor, and dignity. New ideas and economic forms are overwhelming, accompanied by new classes and new discrimination (as shown in Figure 2), which is also the defect of the capitalist system. The implied author realizes the disappearance of the old class and values, but he cannot understand the American dream and capitalism itself, the limitation and obscurity of consumerism and individualism. Only by standing at the height of Marxism can readers profoundly analyze the limitations and ultimately realize the equality and liberation of all mankind.

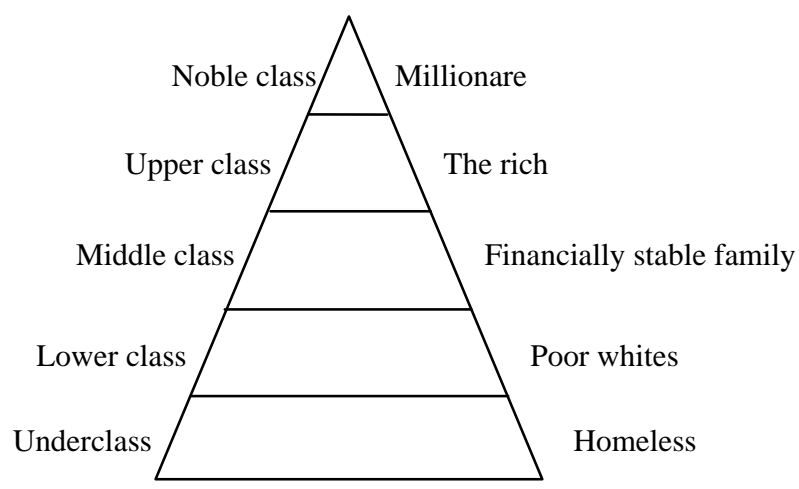

Figure 2. Classes in Modern America.

\section{References}

Elliott, E. (1988). Columbia literary history of the United States. New York: Columbia University Press.

Horton, R., \& Edwards. H. (1974). Backgrounds of American literary thought. London: Pearson College Div.

Shen, D. (2015). Western narratology: Classics and post-classics. Beijing: Peking University Press.

Tyso, L. (2014). Practical guide to contemporary critical theory. (G. X. Zhao et al., Trans.). Beijing: Foreign Language Teaching and Research Press.

Yu, J. H. (2010). English short story course. Beijing: Higher Education Press. 